\title{
Ecotoxicity of In-Situ Produced Compost Intended for Landfill Restoration
}

\author{
Magdalena Daria Vaverková 1,2,*(D), Dana Adamcová ${ }^{1}$, Maja Radziemska ${ }^{2} \mathbb{D}$, Jan $^{\text {Zloch }}{ }^{1}$, \\ Martin Brtnický ${ }^{3}$, Ondřej Šindelář ${ }^{1}$, Alžbeta Maxiánová ${ }^{1}$ and Zbigniew Mazur ${ }^{4}$ \\ 1 Faculty of AgriSciences, Department of Applied and Landscape Ecology, Mendel University in Brno, \\ Zemědělská 1, 61300 Brno, Czech Republic; dana.adamcova@mendelu.cz (D.A.); \\ jan.zloch@mendelu.cz (J.Z.); sindelarO@seznam.cz (O.Š.); alzbeta.maxianova@gmail.com (A.M.) \\ 2 Faculty of Civil and Environmental Engineering, Department of Environmental Improvement, Warsaw \\ University of Life Sciences-SGGW, 159 Nowoursynowska Av., 02-773 Warsaw, Poland; \\ maja_radziemska@sggw.pl \\ 3 Faculty of Forestry and Wood Technology, Department of Geology and Pedology, Mendel University in \\ Brno, Zemědělská 3, 61300 Brno, Czech Republic; martin.brtnicky@seznam.cz \\ 4 Faculty of Environmental Management and Agriculture, Department of Environmental Chemistry, \\ University of Warmia and Mazury in Olsztyn, Pl. Łódzki 4, 10-727 Olsztyn, Poland; \\ zbigniew.mazur@uwm.edu.pl \\ * Correspondence: magda.vaverkova@uake.cz; Tel.: +420-725-244-401
}

Received: 10 September 2018; Accepted: 4 October 2018; Published: 8 October 2018

\begin{abstract}
Municipal solid waste (MSW) has become a matter of increasing global concern. Biological conversion is considered to be the most applicable disposal method, especially for the organic fraction of MSW. The aim of this study was to evaluate composting as a treatment method for the sustainable management and recycling of MSW and to test the ecotoxicity of the compost produced on the landfill surface. The ecotoxicity of the compost was investigated by means of a set of biological tests. The ecotoxicological impact of the compost was evaluated by plant growth tests with white mustard (Sinapis alba L.) and barley (Hordeum vulgare L.). Plants were grown under controlled conditions for 21 days, in earthen pots, treated with MSW compost (MSWC) to study the effect of MSWC on plant biomass production. Sprouts and the number of growing plants occurring in the earthen pots were counted. The values obtained from three simultaneously conducted experiments were averaged and presented. Plants growing in the earthen pots with the compost exhibited increasing plant biomass while no changes were observed in their appearance; retarded growth or necrotic changes were not recorded. The ecotoxicity tests performed show that the analyzed compost produced in the composting plant situated on the landfill surface achieved high percentages of the germinating capacity of white mustard (Sinapis alba L.) and barley (Hordeum vulgare L.) seeds and can be therefore used in the subsequent reclamation of the landfill concerned.
\end{abstract}

Keywords: landfill; compost; ecotoxicity tests; Sinapis alba L.; Hordeum vulgare L.

\section{Introduction}

An estimated $1.3-1.9 \times 10^{15} \mathrm{~kg}$ of municipal solid waste (MSW) is produced every year worldwide. This amount is expected to grow roughly to $2.2 \times 10^{15} \mathrm{~kg}$ MSW per year by 2025 and thus it is becoming the subject of global concern [1,2]. The best method for eliminating organic fractions, particularly in case of MSW, is biological conversion [3,4]. MSW comprises a considerable degree of organic waste that can be efficiently and inexpensively used for composting. This method may increase the content of organic components in soil and protect the environment [4]. Economically, composting is a superior way of treating waste to incineration $[4,5]$. 
EU Directive 1999/31/EC on the landfill of waste sets objectives for reducing the amount of biodegradable MSW deposited in a landfill. By 2010, the amount should be reduced to $75 \%$ compared to 1999 and to $35 \%$ by 2020 [6]. By removing organic compounds from waste deposited in a landfill the landfill gases, for instance $\mathrm{CH}_{4}$ or $\mathrm{CO}_{2}$ [7] will subsequently drop. Compared to landfilling the biodegradable fraction of MSW, the alternative of high technology composting, including the separation of waste, is a much more economic and efficient way of treating waste.

Biological treatment such as composting of the organic fraction of MSW (OFMSW) is an environmentally and economically viable solution [8]. Composting of OFMSW is seen as a method of diverting organic waste materials from landfills while creating a product, at low-cost, that is suitable for reclamation purposes [9]. Composting on the landfill surface brings many benefits. A closed landfill cell is a very suitable and safe space for composting. In addition, it has a positive effect on the limitation of transport, emission and noise. The waste is managed in one place. This strategy (composting plants located on the closed landfill cell) is not very obvious or widely used. In a typical landfill, much of the waste containing $60 \%$ or more in organic content is buried [10]. However, at the Kuchyňky landfill the OFMSW is transformed to compost and used at the same place.

Working compost into the soil [11] is the most common way of raising soil productivity and replacing organic matter $(\mathrm{OM})$ losses in agriculture. Greenhouse gas emissions may be diminished by adding compost as a soil conditioner or fertilizer. Biogenic carbon in soils is sequestered. Compost application improves the physical characteristics of soil, thus returning the basic nutrients back to the soil. Directives regulating the quality of compost have been established in a number of countries [7].

Due to a lack of commonly used materials for compost making, MSW compost (MSWC) is used to make compost for agricultural purposes. The demand for MSWC keeps growing and its application is becoming more and more popular [12].

However, working MSWC into the soil may involve certain health and environmental risks that are often neglected. Solid waste may be contaminated with chemically and biologically harmful substances that embody health risks for people [13]. The quality of compost may have both positive and negative impacts on plant viability. Many physicochemical parameters (temperature, $\mathrm{pH}$, proportion of carbon and nitrogen or the contents of nutrients) may be organic compost stabilization indicators [14]. However, these parameters do not deliver sufficient information on the residues in MSW or indicate whether their application for agricultural purposes is environmentally safe [14,15]. Using the additional method of assessing ecotoxicity is advantageous in determining compost stabilization $[14,16,17]$. The ecotoxicity test monitors the germination of seeds of various species of plant as indicators of biological responses to the stabilization of biosolids [14]. Therefore, the objective of this study is to assess composting as one of the methods of sustainable MSW and its recycling and to carry out ecotoxicity tests on compost samples produced on the surface of the landfill. The ecotoxicological impact of the compost was tested using ecotoxicity tests with white mustard (Sinapis alba L.) and barley (Hordeum vulgare L.).

\section{Materials and Methods}

\subsection{Site Description}

For this research the Kuchyňky active landfill site located near the medium-sized city of Zdounky (population of 75,000$)$ in the Czech Republic (CR) was used (Figure 1). The landfill $\left(49^{\circ} 14.458 \mathrm{~N}\right.$, $17^{\circ} 18.527 \mathrm{E}$ ) is located $1.5 \mathrm{~km}$ from the town center. The landfill is classified in the S-category-other waste, S-OO3 subgroup with separate landfill subgroups of S-OO1 under Ministry of the Environment Decree No. 294/2005 Coll., on the conditions of depositing waste in landfills and its use on the surface of the ground and amending Decree No. 383/2001 Coll., on details of waste management. The landfill has a degazation system and protective fence. The site is fenced off, covering 18.4 ha site. The landfill area covers $70,700 \mathrm{~m}^{2}$ in five stages with a total volume of $907,000 \mathrm{~m}^{3}$, i.e. ca. $1,000,000 \times 10^{3} \mathrm{~kg}$ of waste. The body of the landfill in the stage I. takes up 1.9 ha, in stage II.a. 0.55 ha, stage II.b. 0.45 ha 
and 0.75 ha in stage III.a. It has been in operation since 1995. Detailed site operational activities of the landfill sites are reported in Adamcová 2016 [12].

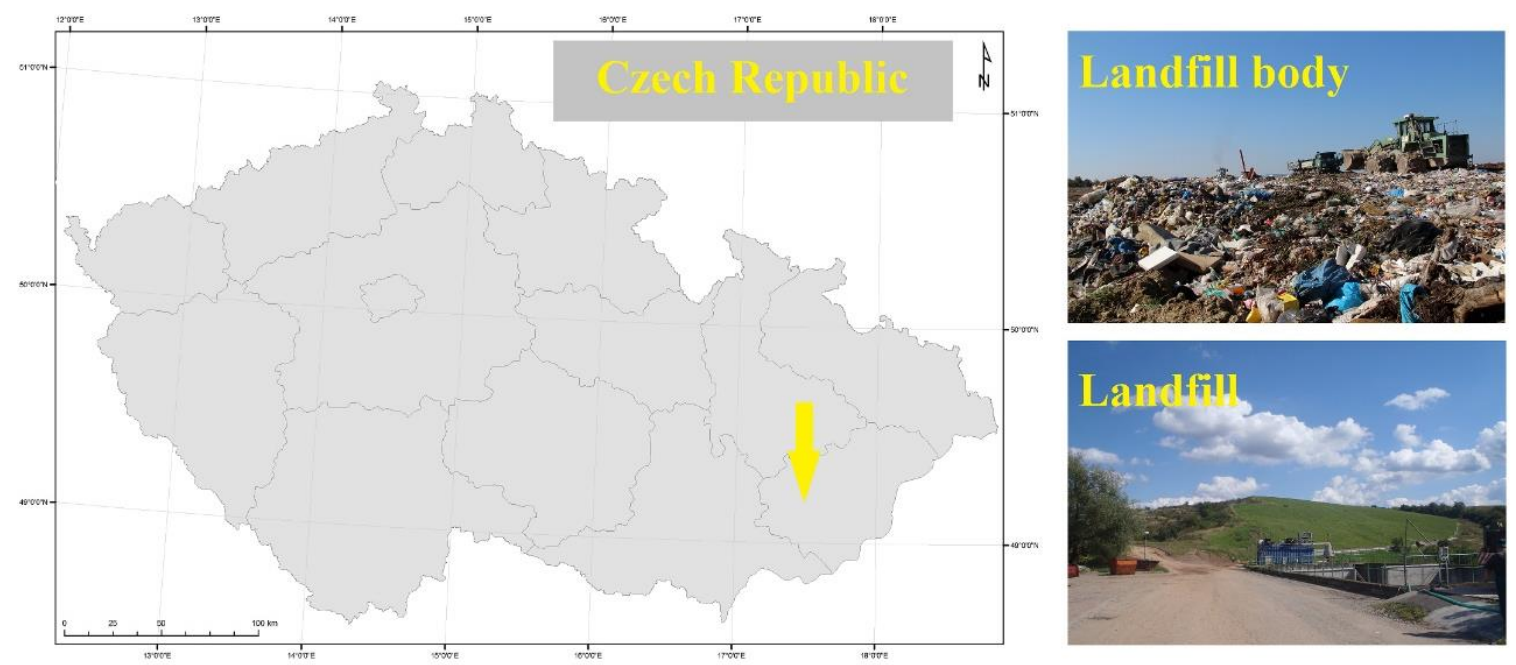

Figure 1. Scheme and aerial photograph (insert) of the landfill site.

\subsection{Composting at the Landfill Body}

The composting plant is located on the surface of the Kuchyňky landfill (Figure 2). Biologically degradable waste (BDW) brought from surrounding villages and towns is composted here. This involves the green stuff from the maintenance of municipal greenery, as well as biologically degradable municipal waste (BDCW) obtained from local people in the collection area.

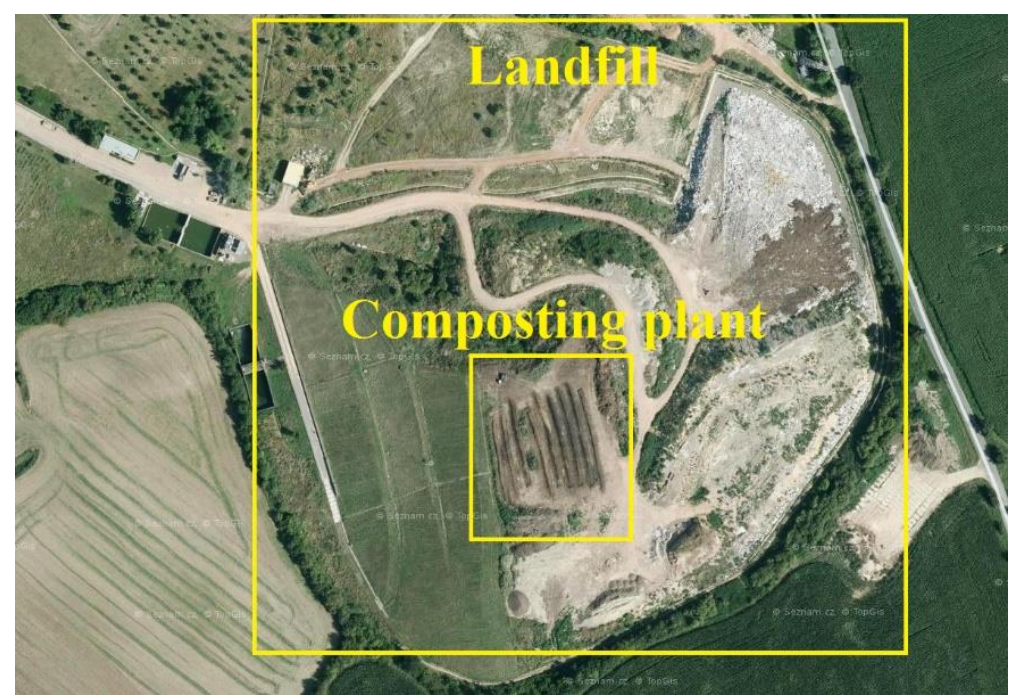

Figure 2. Location of composting plant.

The projected capacity for waste accepted into this composting plant is $2000 \times 10^{3} \mathrm{~kg} /$ year. This site will collect, purchase and use waste-waste management under the R3 code pursuant to attachment No. 3 of the Waste Management Act as later amended. The composting area is located in a site where waste depositing has already come to an end. The place had been restored, covered with recycled material and soil and compacted. The acreage of the composting site is $20 \times 30 \mathrm{~m}$. It consists of $6-8$ composting piles with a $30 \times 1.5 \mathrm{~m}$ triangular profile $0.8 \mathrm{~m}$ high (Figure 3 ). The produced compost is used as a reclamation material for the Kuchyňky landfill [12]. Aerobic conditions were 
accomplished by mechanical turning. The turning was accomplished with specialized equipment. Composting piles were turned upside down every 7 days.
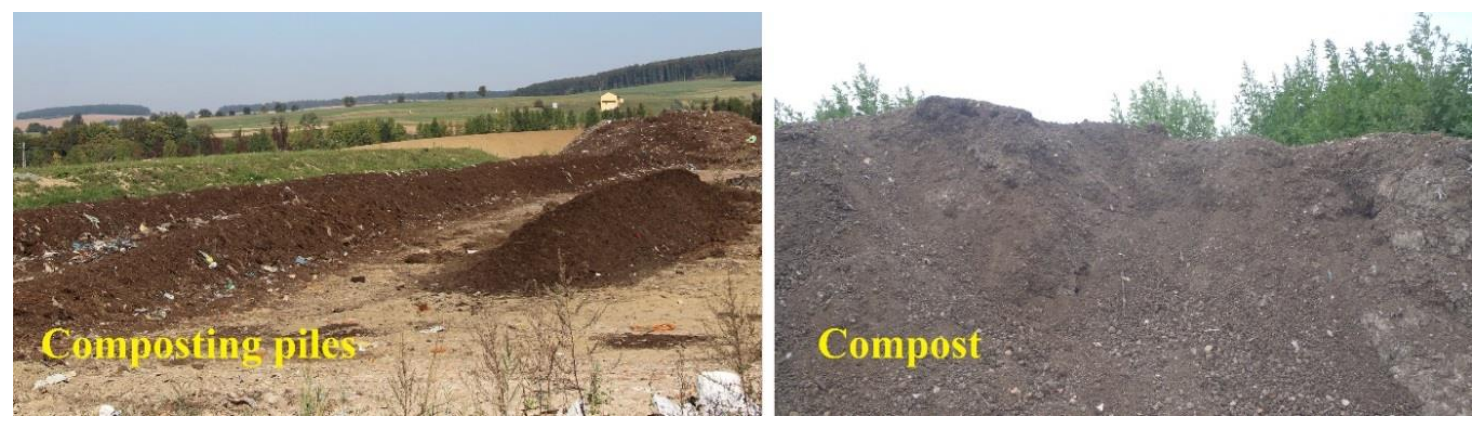

Figure 3. Composting piles located on the landfill surface and ready compost.

\subsection{Composting Materials}

The OFMSW includes food waste, leaf and yard waste. A significant proportion of organic material represents a food waste from restaurants and hospitals or comes from distribution and retail agents. Leaf and yard waste consists of lignocellulose-based materials, such as green grass clippings and thatch, leaves, weeds, brush, and tree prunings, whose production varies widely through the year. A further, although minor, contribution to the lignocellulose content of organic MSW is provided by soiled paper. The basic physico-chemical characteristics of the compost are presented in Table 1.

Table 1. Physico-chemical characteristics of the compost.

\begin{tabular}{ccc}
\hline Parameters & Results & Unit \\
\hline $\mathrm{DM}$ & 41.56 & $\%$ \\
$\mathrm{pH}$ & 6.5 & \\
$\mathrm{C} / \mathrm{N}$ & 32 & $\mu \mathrm{S} / \mathrm{cm}$ \\
Conductivity & 169 & $\% \mathrm{DM}$ \\
Organic carbon & 35 & $\% \mathrm{DM}$ \\
Total nitrogen & 1.21 & $\mathrm{~g} / \mathrm{kg} \mathrm{DM}$ \\
Phosphorus & 2.65 & $\mathrm{~g} / \mathrm{kg} \mathrm{DM}$ \\
Potassium & 11.9 & $\mathrm{mg} / \mathrm{kg} \mathrm{DM}$ \\
Zinc & 178 & $\mathrm{mg} / \mathrm{kg} \mathrm{DM}$ \\
Cadmium & 0.58 &
\end{tabular}

DM: dry matter.

\subsection{Sampling Strategy}

Compost samples were collected from April through September 2017. The frequency of collecting the samples was once a month. Samples ( $2 \mathrm{~kg} / \mathrm{sample})$ were collected in sterile collection containers. The samples were stored in airtight polyethylene containers and transported to the laboratory for analysis. Changes and toxic effect of composts were determined using Sinapis alba L. and Hordeum vulgare $\mathrm{L}$. The samples were always collected at the end of the composting process from the selected pile. Remaining samples were kept (for further analysis) in a freezer at $-18{ }^{\circ} \mathrm{C}$ in the dark in order to keep its characteristics constant.

\subsection{Ecotoxicity Test}

The experiment was carried out in laboratory conditions. The effect of compost ecotoxicity on the plant biomass was determined with: white mustard (Sinapis alba L.-SIA) and barley (Hordeum vulgare L. - HOV) bioassays. Plant seeds were the indicators for the ecotoxicity test, following procedures adapted from those described in CSN EN 13432 Packaging-Requirements for packaging recoverable through 
composting and biodegradation-Test scheme and evaluation criteria for the final acceptance of packaging. The medium was commercial potting soil for germination and plant growth and silica sand (8:2), enriched with compost $(25 \%, 50 \% w / w)$. A soil sample ( $85 \%$ air-dried quartz sand, $10 \%$ kaolin clay, $5 \%$ sphagnum peat, calcium carbonate) without compost amendment was used as a control. After air-drying the medium was sieved with a $2 \mathrm{~mm}$ standard sieve and stored until analyses were provided. Experimental earthen pots were filled with $200 \mathrm{~g}$ of medium, then 100 seeds were scattered onto the surface, covered with a thin layer of silica sand and the pots were covered with a glass plate (to avoid evaporation). Seeds used for the pot experiment were commercially available seeds. When the germinated and growing plants touched the glass plates they were removed. Plants were grown under general laboratory conditions for 21 days. Humidity (at a level of $70 \%$ of water absorption capacity), the low light intensity and the laboratory temperature $\left(22 \pm 2{ }^{\circ} \mathrm{C}\right)$, were kept constant. There were three replicates per treatment. The results obtained were averaged. During the experiment the missing water (evaporated water) was refilled as needed.

\subsection{Determination of Biomass}

Biomass samples (Wet-W, Dry-D: SIA 25\% W, SIA 50\% W, HOV 25\% W, HOV 50\% W and SIA $25 \%$ D, SIA $50 \%$ D, HOV 25\% D, HOV 50\% D) were collected and weighed on Precisa 4000 C scales. The biomass was inserted into paper bags and dried in an ECOCELL dryer (at $45 \pm 2{ }^{\circ} \mathrm{C}$ ). After drying, the biomass was weighed on Precisa $4000 \mathrm{C}$ scales. The results are shown in Table 2 and Figure 5.

The results were subjected to statistical analysis calculating mean values and standard deviations. Significant differences between objects were determined using two-factor analysis of variance (ANOVA) and Duncan's test at the significance level of $p<0.05$, using the Statistica software package (StatSoft Polska, Crakow, Poland) [18].

\section{Results}

The compost produced in the given composting plant was sampled. The samples were designated as A (April), B (May), C (June), D (July), E (August) and F (September). After 14 and 21 days, the number of growing plants and plant biomass were assessed for A-F samples. The number of growing plants and plant biomass was evaluated (Figure 4).
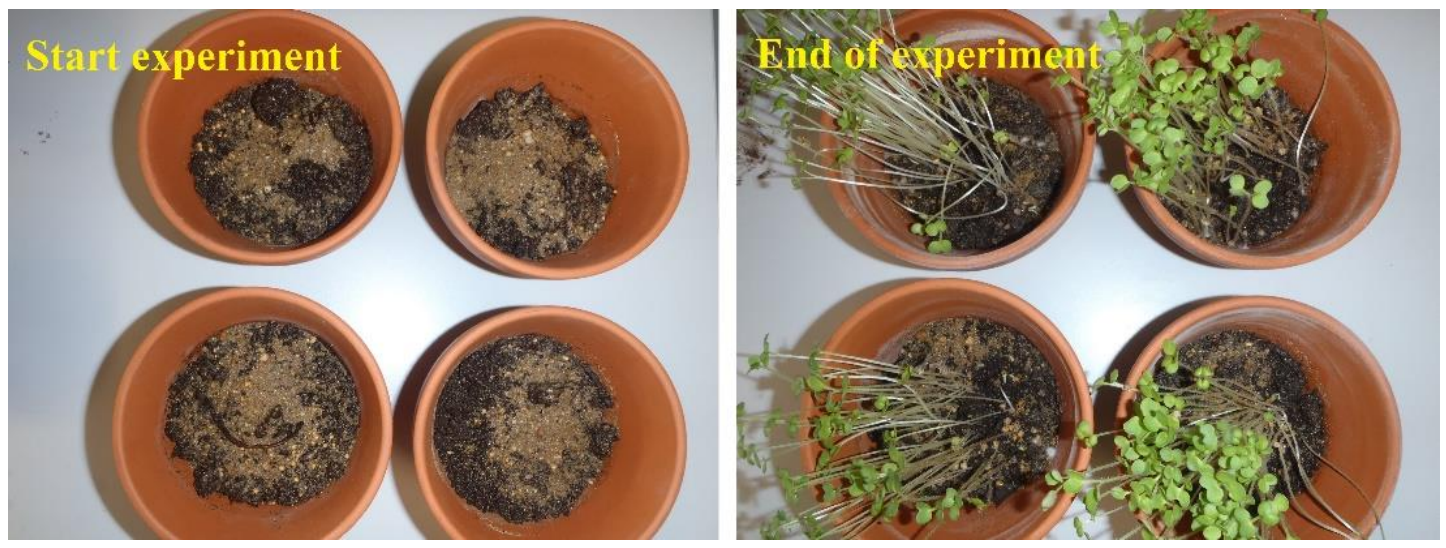

Figure 4. Illustration of the plant biomass of Sinapis alba L. and Hordeum vulgare L.

Figure 5 presents percentages of the number of growing plants of white mustard (Sinapis alba L.) and barley (Hordeum vulgare L.) seeds ( $25 \%, 50 \%$ of samples A-F) after 21 days from the beginning of the experiment. 


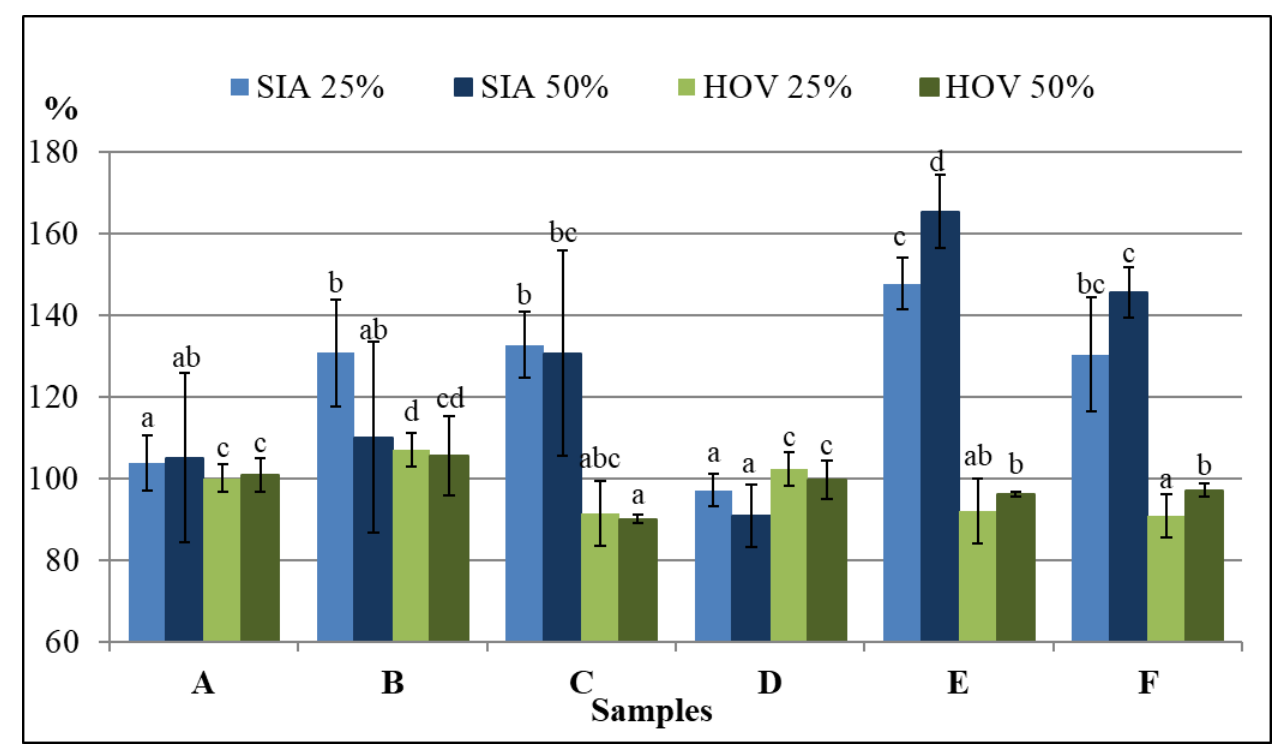

Figure 5. Comparison of the percentages of the growing plants in (A-F) compost samples. Mean values \pm standard deviation $(n=3)$. Different letters indicate significant differences between number of growing plants for the same plant, $p<0.05$.

The germinating capacity of seeds and plant growth were $97-148 \%$ for SIA $25 \%$ A-F samples and 91-165\% for SIA $50 \%$ A-F samples. The average germinating capacity was $124 \%$ for SIA $25 \%$ A-F samples and $125 \%$ for SIA 50\% A-F samples. The germinating capacity of seeds and plant growth were $91-107 \%$ for HOV $25 \%$ A-F samples and $90-105 \%$ for HOV $50 \%$ A-F samples. The average germinating capacity was $97 \%$ for HOV $25 \%$ A-F samples and $98 \%$ for HOV 50\% A-F samples. The highest germinating capacity of seed was achieved in samples SIA 50\% A-F. Pursuant to the standard, values below $90 \%$ are considered slightly toxic. Only sample HOV $50 \%$ C was toxic. Samples HOV 25\% A-F and HOV 50\% A-F have a lower germinating capacity than samples SIA $25 \%$ and SIA $50 \%$, on average by $27 \%$.

The weight biomass of white mustard (Sinapis alba L.) and barley (Hordeum vulgare L.) are shown in Table 2.

Table 2. Weight biomass of white mustard (Sinapis alba L.) and barley (Hordeum vulgare L.).

\begin{tabular}{ccccc}
\hline Sinapis alba $\mathbf{L}$. & \multicolumn{2}{c}{$\mathbf{2 5 \%}$} & \multicolumn{2}{c}{$\mathbf{5 0} \%$} \\
\hline (g) & $\mathbf{W}$ & $\mathbf{D}$ & $\mathbf{W}$ & $\mathbf{D}$ \\
\hline $\mathbf{A}$ & $1.21 \mathrm{~b}$ & $0.3 \mathrm{c}$ & $1.25 \mathrm{bc}$ & $0.29 \mathrm{c}$ \\
$\mathbf{B}$ & $0.96 \mathrm{a}$ & $0.34 \mathrm{~d}$ & $1.01 \mathrm{a}$ & $0.28 \mathrm{c}$ \\
$\mathbf{C}$ & $1.11 \mathrm{~b}$ & $0.33 \mathrm{~d}$ & $1.17 \mathrm{~b}$ & 0.36 \\
$\mathbf{D}$ & $1.61 \mathrm{~d}$ & $0.34 \mathrm{~d}$ & $1.22 \mathrm{~b}$ & $0.15 \mathrm{a}$ \\
$\mathbf{E}$ & $1.31 \mathrm{bc}$ & $0.25 \mathrm{~b}$ & $1.21 \mathrm{~b}$ & $0.24 \mathrm{~b}$ \\
$\mathbf{F}$ & $1.46 \mathrm{c}$ & $0.25 \mathrm{~b}$ & $1.58 \mathrm{~d}$ & $0.35 \mathrm{~d}$ \\
\hline Hordeum vulgare $\mathbf{L}$. & \multicolumn{2}{c}{$\mathbf{2 5 \%}$} & \multicolumn{3}{c}{$\mathbf{5 0} \%$} \\
\hline $\mathbf{A}$ & $14.75 \mathrm{~d}$ & $1.13 \mathrm{c}$ & $14.44 \mathrm{c}$ & $1.16 \mathrm{~d}$ \\
$\mathbf{B}$ & $13.48 \mathrm{~b}$ & $1.11 \mathrm{~b}$ & $15.6 \mathrm{~d}$ & $1.18 \mathrm{~d}$ \\
$\mathbf{C}$ & $12.65 \mathrm{a}$ & $1.04 \mathrm{a}$ & $11.42 \mathrm{a}$ & $0.9 \mathrm{a}$ \\
$\mathbf{D}$ & $14.6 \mathrm{~cd}$ & $1.12 \mathrm{bc}$ & $16.47 \mathrm{e}$ & $1.34 \mathrm{e}$ \\
$\mathbf{E}$ & $14.47 \mathrm{c}$ & $1.14 \mathrm{c}$ & $18.5 \mathrm{f}$ & $1.50 \mathrm{f}$ \\
$\mathbf{F}$ & $13.01 \mathrm{~b}$ & $0.98 \mathrm{a}$ & $15.23 \mathrm{~d}$ & $1.35 \mathrm{e}$ \\
\hline
\end{tabular}

Mean values $(n=3)$. Different letters indicate significant differences between weight biomass for the same plant and kind of weight, $p<0.05$.

In the period under scrutiny, the weight of wet biomass for the test plant Sinapis alba L. with $25 \%$ proportion, oscillated between 0.96 and $1.61 \mathrm{~g}$. The average weight of wet biomass for all tested 
samples was $1.28 \mathrm{~g}$. In the case of $50 \%$ proportion of the tested compost, the weight of the wet biomass oscillated between 1.0 and $1.58 \mathrm{~g}$, and the average value was $1.24 \mathrm{~g}$. The choice of the proportion of tested compost samples in the case of Sinapis alba L. therefore did not affect the wet biomass weight. Individual compost samples (A-F) manifested similar results of wet biomass weight in the case of both tested proportions of $25 \%$ and $50 \%$, while no sample of the tested composts showed any distinctive deviation in the wet biomass weight. Comparable results were ascertained also in the case of dry biomass weight for the tested Sinapis alba L. In the period under scrutiny, the weight of the dry biomass in the case of $25 \%$ proportion oscillated between 0.25 and $0.34 \mathrm{~g}$, and the average weight of dry biomass in all tested samples was $0.30 \mathrm{~g}$. In the case of $50 \%$ proportion the weight of the dry biomass oscillated between 0.15 and $0.36 \mathrm{~g}$, and the average value was $0.28 \mathrm{~g}$.

In the period under scrutiny, the weight of the wet biomass for the tested plants of Hordeum vulgare $\mathrm{L}$. with $25 \%$ proportion oscillated between 12.65 and $14.75 \mathrm{~g}$, and the average weight of wet biomass from all the tested samples was $13.83 \mathrm{~g}$. In the case of a $50 \%$ proportion of the tested compost the weight of the wet biomass oscillated between 11.42 and $18.50 \mathrm{~g}$, and the average value was $15.28 \mathrm{~g}$. The choice of the proportion of tested compost samples in case of the Hordeum vulgare L. plant therefore did not influence the weight of the wet biomass. Individual compost samples (A-F) manifested similar results of wet biomass weights in the case of both tested proportions of $25 \%$ and $50 \%$, while no sample of the tested composts showed any distinctive deviation in the wet biomass weight. Comparable results were ascertained also in the case of dry biomass for the tested Hordeum vulgare L. plant. Within the period under scrutiny the weights of dry biomass with a $25 \%$ proportion oscillated between 0.98 and $1.14 \mathrm{~g}$, and the average value of dry biomass for all tested samples was $1.09 \mathrm{~g}$. In the case of the $50 \%$ proportion of tested compost samples, the weight of the dry biomass oscillated between 0.90 and $1.35 \mathrm{~g}$, and the average value was $1.24 \mathrm{~g}$.

The samples A-F Sinapis alba L. have a higher weight of dry and wet biomass under the $25 \%$ compost proportion than with the $50 \%$ compost proportion. Horedeum vulgare L. showed (April-September) a higher weight of dry and wet biomass with the $50 \%$ proportion of the tested compost than the $25 \%$ one.

\section{Discussion}

Composting significantly reduces the volume of waste while simultaneously producing valuable soil amendment product $[19,20]$. Numerous studies have been carried out to define the chemical, physical and microbiological characteristics of the composting process [20-23] and of compost as fertilizer, but such research aimed to analyze the ecotoxicity of compost and possibility of using compost produced on the closed landfill cell are not yet exhaustive. In order to use compost produced in non-standard conditions (MSW landfills create very specific conditions), an ecotoxic analysis of this product is needed. In our study all the composts do not manifest ecotoxicity. This finding provides evidence that compost produced on the landfill surface can bring many environmental benefits e.g., biodegradable waste not being landfill, emissions of greenhouse gases are avoided reduction of transport, emission and noise. The material is used at the place where it has been produced which is in accordance with resource management. Moreover, there is a necessity of the quick reclamation of the full landfill cells $[24,25]$. After the cells are closed, the impact of waste on the environment will be minimized.

\section{Conclusions}

Landfilling is the worst waste management option for the organic fraction of municipal solid waste. Composting on the closed landfill cell is a promising method for effective and environmentally friendly use of biodegradable waste. The most significant benefits of proper biodegradable waste management-besides avoiding emissions of greenhouse gases—is the production of good quality compost. Samples from the compost under scrutiny show no ecotoxic effect. It is therefore possible to use the tested compost as a soil amendment or landfill cover material. This is substantiated 
by the results of the biomass for both tested plants, white mustard (Sinapis alba L.) and barley (Hordeum vulgare L.).

Author Contributions: Conceptualization, M.D.V., D.A. and M.R.; methodology; D.A., J.Z., Z.M. and A.M.; validation, M.D.V, D.A. and M.R.; formal analysis, J.Z., M.B. and Z.M.; investigation, M.D.V., D.A., O.Š. and M.R.; data curation, M.D.V., D.A., J.Z. and Z.M.; writing—original draft preparation, M.D.V., D.A. and M.R.; writing-review and editing, M.D.V., M.R.; visualization, D.A.

Funding: This research was financially supported by the IGA FA MENDELU No. TP 003/2018.

Conflicts of Interest: The authors declare no conflicts of interest.

\section{References}

1. Filho, W.L.; Brandli, L.; Moora, H.; Kruopienė, J.; Stenmarck, Å. Benchmarking approaches and methods in the field of urban waste management. J. Clean. Prod. 2015, 112, 4377-4386. [CrossRef]

2. Jara-Samaniego, J.; Pérez-Murcia, M.D.; Bustamante, M.A.; Pérez-Espinosa, A.; Paredes, C.; López, M.; López-Lluch, D.B.; Gavilanes-Terán, I.; Moral, R. Composting as sustainable strategy for municipal solid waste management in the Chimborazo Region, Ecuador: Suitability of the obtained composts for seedling production. J. Clean. Prod. 2017, 141, 1349-1358. [CrossRef]

3. Montejo, C.; Tonini, D.; Marquez, M.C.; Astrup, T.F. Mechanical-biological treatment: Performance and potentials. An LCA of 8 MBT plants including waste characterization. J. Environ. Manag. 2013, 128, 661-673. [CrossRef] [PubMed]

4. Rasapoor, M.; Adl, M.; Pourazizi, B. Comparative evaluation of aeration methods for municipal solid waste composting from the perspective of resource management: A practical case study in Tehran, Iran. J. Environ. Manag. 2016, 184, 528-534. [CrossRef] [PubMed]

5. Cukjati, N.; Zupančic, G.D.; Roš, M.; Grilc, V. Composting of anaerobic sludge: An economically feasible element of a sustainable sewage sludge management. J. Environ. Manag. 2012, 106, 48-55. [CrossRef] [PubMed]

6. EU. Council Directive 1999/31/EC of the 26 April 1999 on the Landfill of Waste Council of the European Union. European Union, 1999. Available online: https:/ / eur-lex.europa.eu/legal-content/en/TXT/?uri= CELEX\%3A31999L0031 (accessed on 10 September 2018).

7. Stamou, I.; Antizar-Ladislao, B. A life cycle assessment of the use of compost from contaminated biodegradable municipal solid waste with silver and titanium dioxide nanoparticles. J. Clean. Prod. 2016, 135, 884-891. [CrossRef]

8. López, M.; Soliva, M.; Martínez-Farré, F.X.; Fernández, M.; Huerta-Pujol, O. Evaluation of MSW organic fraction for composting: Separate collection or mechanical sorting. Resour. Conserv. Recycl. 2010, 54, 222-228. [CrossRef]

9. Salati, S.; Scaglia, B.; di Gregorio, A.; Carrera, A.; Adani, F. Mechanical biological treatment of organic fraction of MSW affected dissolved organic matter evolution in simulated landfill. Bioresour. Technol. 2013, 142, 115-120. [CrossRef] [PubMed]

10. Steven, W.; Durany-Fernandez, P.; Sapsford, D.; Cleall, P.C.; Harbottle, M. Altered chemical evolution in landfill leachate post implementation of biodegradable waste diversion. Waste Manag. Res. 2018. [CrossRef]

11. Murray, H.; Pinchin, T.A.; Macfie, S.M. Compost application affects metal uptake in plants grown in urban garden soils and potential human health risk. J. Soil Sediment 2011, 11, 815-829. [CrossRef]

12. Adamcová, D.; Vaverková, M.D. Does composting of biodegradable municipal solid waste on the landfill body make sense? J. Ecol. Eng. 2016, 17, 30-37. [CrossRef]

13. Cesaro, A.; Belgiorno, V.; Guida, M. Compost from organic solid waste: Quality assessment and European regulations for its sustainable use. Resour. Conserv. Recy. 2015, 94, 72-79. [CrossRef]

14. Mendes, P.M.; Becker, R.; Corrêa, L.B.; Bianchi, I.; Dai Prá, M.A.; Lucia, T.; Corrêa, E.K. Phytotoxicity as an indicator of stability of broiler production residues. J. Environ. Manag. 2016, 167, 156-159. [CrossRef] [PubMed]

15. Jurado, M.M.; Suárez-Estrella, F.; Vargas-García, M.C.; López, M.J.; López-González, J.A.; Moreno, J. Evolution of enzymatic activities and carbon fractions throughout composting of plant waste. J. Environ. Manag. 2014, 133, 355-364. [CrossRef] [PubMed] 
16. Delgado, M.M.; Rodriquez, C.; Martin, J.V.; Imperial, R.M.; Alonso, F. Environmental assay on the effect of poultry manure application on soil organisms in Agroecosystems. Sci. Tot. Environ. 2012, 6, 532-535. [CrossRef] [PubMed]

17. Galende, M.; Becerril, J.; Gómez-Sagasti, M.; Barrutia, O.; Garbisu, C.; Hernández, A. Agro-industrial wastes as effective amendments for ecotoxicity reduction and soil health improvement in aided phytostabilization. Environ. Sci. Pollut. R. 2014, 17, 10036-10044. [CrossRef] [PubMed]

18. StatSoft. Available online: http://www.statsoft.com/Products/STATISTICA-Features (accessed on 10 September 2018).

19. Varma, V.S.; Kalamdhad, A.S. Effects of leachate during vegetable waste composting using rotary drum composter. Environ. Eng. Res. 2014, 19, 67-73. [CrossRef]

20. Muscolo, A.; Papalia, T.; Settineri, G.; Mallamaci, C.; Jeske-Kaczanowska, A. Are raw materials or composting conditions and time that most influence the maturity and/or quality of composts? Comparison of obtained composts on soil properties. J. Clean. Prod. 2018, 195, 93-101. [CrossRef]

21. Alburquerque, J.A.; Gonzalvez, J.; Garcia, D.; Cegarra, J. Effects of bulking agent on the composting of "alperujo", the solid by-product of the two-phase centrifugation method for olive oil extraction. Process Biochem. 2006, 41, 127-132. [CrossRef]

22. Baeta-Hall, L.; Sàagua, M.C.; Bartolomeu, M.L.; Anselmo, A.M.; Rosa, M.F. Biodegradation of olive husks in composting aerated piles. Bioresour. Technol. 2005, 96, 69-78. [CrossRef] [PubMed]

23. Canet, R.; Pomares, F.; Cabot, B.; Chaves, C.; Ferrer, E.; Ribó, M.; Albiach, M.R. Composting olive mill pomace and other residues from rural southeastern Spain. Waste Manag. 2008, 28, 585-2592. [CrossRef] [PubMed]

24. Jain, P.; Townsend, T.G.; Johnson, P. Case study of landfill reclamation at a Florida landfill site. Waste Manag. 2013, 33, 109-116. [CrossRef] [PubMed]

25. Weng, Y.-C.; Fujiwara, T.; Houng, H.J.; Sun, C.-H.; Li, W.-Y.; Ku, Y.-W. Management of landfill reclamation with regard to biodiversity preservation, global warming mitigation and landfill mining: Experiences from the Asia-Pacific region. J. Clean. Prod. 2015, 104, 364-373. [CrossRef]

(C) 2018 by the authors. Licensee MDPI, Basel, Switzerland. This article is an open access article distributed under the terms and conditions of the Creative Commons Attribution (CC BY) license (http:/ / creativecommons.org/licenses/by/4.0/). 